\title{
Peran Adopsi Teknologi Media Sosial terhadap Niat Berwirausaha Mahasiswa Rekayasa Politeknik Negeri Bandung
}

\begin{abstract}
Received:
11 November

2020

Revision

received:

13 Desember

2021

Accepted:

20 Desember

2021

\author{
Harmon Chaniago* dan Abdul Malik Sayuti
}

Jurusan Administrasi Niaga, Politeknik Negeri Bandung, Indonesia

Abstract

Sosial media among Politeknik Negeri Bandung (POLBAN) engineering students is commonly used in carrying out daily activities. It mostly related to students's sosial activities. Sosial media among engineering students has not been aimed at supporting economic value activites such as entrepreneurship. In fact, students have been taken information technology and entrepereneurship courses during their study. This research aims to reveal the extent to which the adoption of sosial media technology by POLBAN engineering students affect on entrepreneurial intention. This research used a quantitaive approach by distributing 313 questionaires to POLBAN engineering students who met the criteria. Data were processed using multiple regression methods to see the influence's size of adoption of sosial media technology on entrepreneurial intentions. The result of this research provide an up-to-date overview of effect of adoption of secial media technology in increasing the growth of entrepreneurial intention among POLBAN engineering students.
\end{abstract}

Keyword: adoption of sosial media technology, entrepreneurial intention, polban engineering students

\begin{abstract}
Abstrak
Media sosial di kalangan mahasiswa jurusan rekayasa Politeknik Negeri Bandung (POLBAN) adalah biasa dan umum digunakan dalam menjalankan kegiatan sehari-hari. Penggunaan ini sebagian besar berkaitan dengan kegiatan bersosialisasi mahasiswa dengan lingkungan sosialnya. Penggunaan media sosial di kalangan mahasiswa rekayasa belum ditujukan mendukung kegiatan-kegiatan yang bernilai ekonomis seperti berwirausaha. Padahal, mahasiswa telah dibekali mata kuliah pemanfaatan teknologi informasi dan kewirausahaan selama perkuliahannya. Penelitian ini bertujuan untuk menyingkap sejauhmana adopsi teknologi media sosial yang dikuasai mahasiswa berpengaruh pada niat berwirausaha mahasiswa di jurusan rekayasa POLBAN. Penelitian ini menggunakan pendekatan kuantitif dengan menyebarkan kuesioner pada 313 mahasiswa jurusan rekayasa POLBAN yang memenuhi kriteria. Data yang didapatkan dari penyebaran kuesioner diolah dengan metode regresi majemuk untuk melihat besar kecilnya pengaruh adopsi teknologi media sosial terhadap niat berwirausaha. Hasil penelitian ini memberikan gambaran terkini terkait adanya pengaruh adopsi teknologi media sosial dalam mendorong tumbuhnya niat berwirausaha di kalangan mahasiswa rekayasa POLBAN.
\end{abstract}

Kata Kunci: adopsi teknologi sosial media, niat berwirausaha, mahasiswa rekayasa polban

\section{Pendahuluan}

Berdasarkan data yang diterbitkan oleh Badan Pusat Statistik pada tahun 2017, terdapat peningkatan pendapatan domestik bruto (PDB) dari usaha kecil menengah di Indonesia. Pada 2015 PDB yang bersumber dari UMKM hanya sebesar 4,88\% dan pada 2016 meningkat menjadi 5,02\% dengan 
peningkatan jumlah UMKM menjadi 4,77\% dengan 39 juta penggerak UMKM (BPS, 2017). Semakin banyak orang yang menyadari bahwa dengan berwirausaha seorang wirausaha dapat memiliki pendapatan yang signifikan, menjadi mandiri dan memiliki kesempatan untuk berekspresi dan menerapkan ide-ide yang ditelurkannya (Ambadar et al., 2007). Wirausaha UMKM harus dapat bersaing dengan baik dengan meningkatkan kreativitas dan inovasi atas produk, layanan atau proses bisnis yang dilakukannya misalnya memanfaatkan teknologi informasi atau media sosial dalam proses bisnisnya (Wijaya, 2008).

Pada tahun 2019 pengguna internet di Indonesia sebanyak 143 juta pengguna dan pengguna media sosial sebanyak 130 juta pengguna (Rizkinaswara, 2019). Jumlah pengguna internet ini mengalami peningkatan dari data Asosiasi Penyelenggara Jasa Internet Indonesia yang menyatakan bahwa tahun 2016 pengguna internet sebanyak 129,2 juta pengguna (Asosiasi Penyelenggara Jasa Internet Indonesia, 2016). Berikut hasil survey yang dilakukan APJII pada tahun 2016 tahun 2016 (Asosiasi Penyelenggara Jasa Internet Indonesia, 2016):

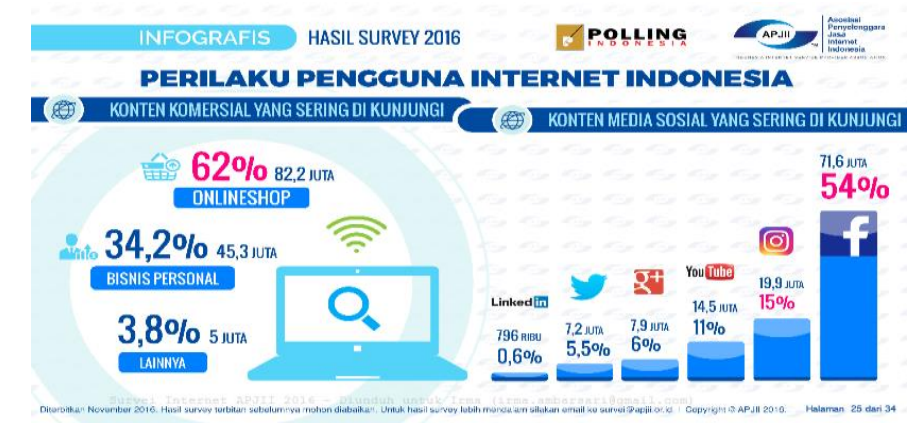

Sumber: Asosiasi Penyelenggara Jasa Internet Indonesia, 2016

Gambar 1 Penggunaan Internet oleh Masyarakat Indonesia

Gambar 1 memperlihatkan bahwa sekitar 62\% (82,2 juta) pengguna internet di Indonesia mengunjungi toko online, $34,2 \%$ (45,3 juta) pengguna mengunjungi konten bisnis personal, dan 1,2\% untuk lainnya. Besarnya jumlah pengguna ini sangat besar manfaatnya jika dimanfaatkan dengan baik oleh wirausaha UMKM. Penggunaan internet dan media sosial meningkatkan promosi, interaksi hingga mendukung proses transaksi antara wirausaha dan konsumen potensialnya.

Mahasiswa adalah pihak yang paling banyak mengadopsi penggunaan internet dan media sosial dalam kehidupan sehari-harinya. Kemampuan ini merupakan potensi yang sangat besar untuk digunakan dalam proses menjalankan usaha (Rodrigues Pinho \& Soares, 2011). Dibutuhkan upaya bagi institusi seperti universitas atau politeknik untuk mendorong mahasiswanya menggunakan potensinya memunculkan/ menjalankan usaha. Dorongan ini juga sangat bermanfaat untuk meningkatkan persentase mahasiswa berwirausaha, karena hingga 2019 ditemukan jumlah mahasiswa vokasi non rekayasa Politeknik Negeri Bandung (POLBAN) yang berniat menjadi wirausaha ada 83,82\% dan menjadi wirausaha 23,30\% dari jumlah lulusan yang ada (Chaniago \& Sayuti, 2019) namun belum diketahui untuk mahasiswa rekayasa. POLBAN telah memberikan bekal kewirausahaan pada seluruh mahasiswanya. Penguasaan teknologi internet dan media sosial, pengetahuan kewirausahaan terbukti memberikan pengaruh signifikan dalam berwirausaha mahasiwa non rekayasa di POLBAN (Chaniago \& Sayuti, 2019).

Penelitian ini merupakan lanjutan dari penelitian sebelumnya yang mengkaji tentang peran adopsi teknologi sosial media terhadap niat berwirausaha mahasiswa non rekayasa di POLBAN. Mahasiswa rekayasa cenderung kreatif dan inovatif dalam menciptakan suatu produk, memperbaiki kondisi dalam arti yang luas dan memecahkan masalah yang berbeda dari pemecahan yang telah diketahui sebelumnya (Badran, 2007). Sebagai contoh mahasiswa JTK memiliki inovasi perangkat lunak, mahasiswa Teknik Mesin mendesain mesin dan peralatan dan lain sebagainya. Tentu saja produk yang dihasilkan tersebut tidak akan mendatangkan keuntungan jika tidak dikomersialisasikan. Salah satu bentuk komersialisasi berupa suatu usaha bisnis yang melibatkan penggunaan media sosial dalam melancarkan kegiatan usaha tersebut. Penelitian ini bertujuan untuk mengetahui sejauhmana adopsi teknologi media sosial yang dikuasai mahasiswa rekayasa POLBAN berperan dalam mendorong niat berwirausaha mahasiwa. 
Penelitian ini diusulkan sebagai penelitian yang dibiayai oleh POLBAN dengan skema pembiayaan Penelitian Pemula. Hasil penelitian ini nantinya akan melengkapi hasil penelitian sebelumnya dan menjadi masukan bagi manajemen POLBAN dalam mengembangkan materi kewirausahaan dan pendampingan kewirausahaan di jurusan rekayasa POLBAN.

\section{Kajian Literatur}

\section{Adopsi Teknologi Media Sosial}

Adopsi teknologi media sosial merujuk pada kegiatan untuk menggunakan teknologi media sosial secara utuh dari mengirim dan menerima permintaan pertemanan, melakukan promosi daring, berkomentar dan sebagainya secara interaktif dengan lawan bicaranya (Fourqoniah, 2015; Roblyer et al., 2010). Dalam teori Technology Acceptance Model (TAM), Davis (1989) menjelaskan bahwa TAM terbagi menjadi dua dimensi yaitu kemudahan menggunakan (ease of use) dan kemanfaatan (usefullness). Penggunaan teknologi terpengaruh pada persepsi pengguna terkait kemudahan dalam menggunakan teknologi tersebut dan manfaat teknologi tersebut dalam kegiatan sehari-harinya. Venkatesh et al. (2003) dalam Theory of Planned Behavior (TPB) menjelaskan bahwa penggunaan teknologi dikarenakan adanya norma atau tekanan sosial yang dirasakan dari orang-orang sekelilingnya, persepsi terkait sumberdaya yang dimiliki, kemampuan dan kemampuan dalam mengendalikan penggunaan teknologi. Rogers (1983) menjelaskan bahwa penggunaan teknologi berkaitan erat dengan dimensi-dimensi relative advantage, compatibility, complexity, trialability dan observability, teori ini dikenal dengan Innovation of Diffussion Theory (IDT).

Penelitian ini menggunakan ketiga teori tersebut dalam menjelaskan variabel terkait adopsi teknologi media sosial. Adopsi teknologi media sosial memiliki dimensi-dimensi yang terdiri dari kemudahan menggunakan, kemanfaatan, tekanan sosial, fasilitas yang dimiliki, kemampuan mengontrol penggunaan, relative advantage, compatability dan complexity. Hal ini dikarenakan penggunaan teknologi khususnya media sosial merupakan hal penting dalam menjalankan dan mengembangkan kegiatan usaha (Pribadi et al., 2018).

\section{Media Sosial}

Media sosial merupakan situs internet yang membantu penggunanya meningkatkan komunikasi interaktif dengan pengguna lainnya tanpa dipisahkan jarak dan besifat real time, menampilkan profil pengguna, hingga mempermudah pengguna melihat aktivitas pengguna media sosial lainnya (Hartati, 2017). Kemampuan pengguna mengadopsi teknologi media sosial membantu pengguna dalam menjalankan usahanya dengan mudah, proses lebih efektif dan lebih efisien (Raymond \& Bergeron, 2008; Sinkovics et al., 2013; Wagner et al., 2003). Penggunaan media sosial dalam proses bisnis mempersingkat waktu yang dibutuhkan dalam proses transaksi, memperpendek jarak antara wirausaha dengan konsumennya (Constantinides et al., 2009).

Taprial dan Kanwar (2012)menyatakan media sosial yang baik dapat membantu pengguna dalam menjalankan kegiatan sehari-harinya, memiliki beberapa kriteria berikut: a) mudah diakses (accessability), b) dapat dibuka/digunakan dengan cepat (speed), c) pengguna terhubung secara interaktif (interactivity), d) dapat diakses dalam waktu lama (longevity), dan e) informasi yang diberikan mudah dijangkau (reach). Media sosial yang sesuai kriteria di atas memainkan peran yang efektif dalam meningkatkan interaksi pengguna dalam menjalankan usaha, untuk terhubung dengan konsumen atau rekan usahanya (Alarcon-del-Amo et al., 2015).

\section{Niat Berwirausaha}

Wirausaha merujuk pada individu/kelompok yang mencari peluang menjalankan usaha, memiliki keberanian mengambil resiko, memanfaatkan sumberdaya yang dimilikinya untuk mendirikan suatu usaha dan menjalankan usaha tersebut dengan efisien agar menghasilkan keuntungan bagi dirinya (Daryanto, 2012; Zimmerer dalam Winardi, 2008). Niat merujuk pada upaya keras individu dalam mencoba dan berusaha mencapai tujuan dan cita-citanya (Wijaya, 2008).

Niat berwirausaha berarti upaya keras individu mendirikan usaha, menghadapi resiko, memperkecil terjadinya resiko dan mengupayakan sumberdaya yang dimilikinya untuk menjalankan 
usaha yang telah didirikan guna mendapatkan keuntungan dari usahanya (Daryanto, 2012; Zimmerer dalam Winardi, 2008; Wijaya, 2008). Niat berwirausaha memiliki kaitan erat dengan upaya individu dalam memanfaatkan ide-ide, kreativitas dan inovasi guna membuka peluang yang ada, memperkecil resiko hingga menjalankan proses bisnis yang memberikan keuntungan bagi usahanya.

\section{Keterkaitan Antar Variabel}

Dalam berbagai penelitian, penggunaan media sosial berperan penting bagi dunia usaha diantaranya dalam bidang pemasaran: promosi dan proses inovasi produk yang ditawarkan (Kim et al., 2008; Piller \& Walcher, 2006). Media sosial memiliki peran meningkatkan minat wirausaha mahasiswa (Fourqoniah, 2015; Liñán \& Santos, 2007). Dalam konteks penggunaan di perusahaan, Alarcon-delAmo (2015) menjelaskan penggunaan media sosial dalam proses bisnis mampu meningkatkan kinerja perusahaan yang dia teliti.

Hipotesis yang dirumuskan dalam penelitian ini adalah sebagai berikut:

Hipotesis 1: Kemanfaatan (usefullness) berpengaruh pada niat berwirausaha mahasiswa rekayasa POLBAN.

Hipotesis 2: $\quad$ Kemudahan menggunakan (ease of use) berpengaruh pada niat berwirausaha mahasiswa rekayasa POLBAN.

Hipotesis 3: Tekanan sosial (sosial factor) berpengaruh pada niat berwirausaha mahasiswa rekayasa POLBAN.

Hipotesis 4: $\quad$ Fasilitas yang dimiliki (facilitating condition) berpengaruh pada niat berwirausaha mahasiswa Rekayasa POLBAN.

Hipotesis 5: Kontrol pengguna (perceived control) berpengaruh pada niat berwirausaha mahasiswa rekayasa POLBAN.

Hipotesis 6: $\quad$ Relative advantage berpengaruh pada niat berwirausaha mahasiswa rekayasa POLBAN.

Hipotesis 7: Compatability berpengaruh pada niat berwirausaha mahasiswa rekayasa POLBAN.

Hipotesis 8: Kompleksitas (complexity) berpengaruh pada niat berwirausaha mahasiswa rekayasa POLBAN.

Berikut gambaran konseptual penelitian yang akan dilakukan dalam penelitian ini:

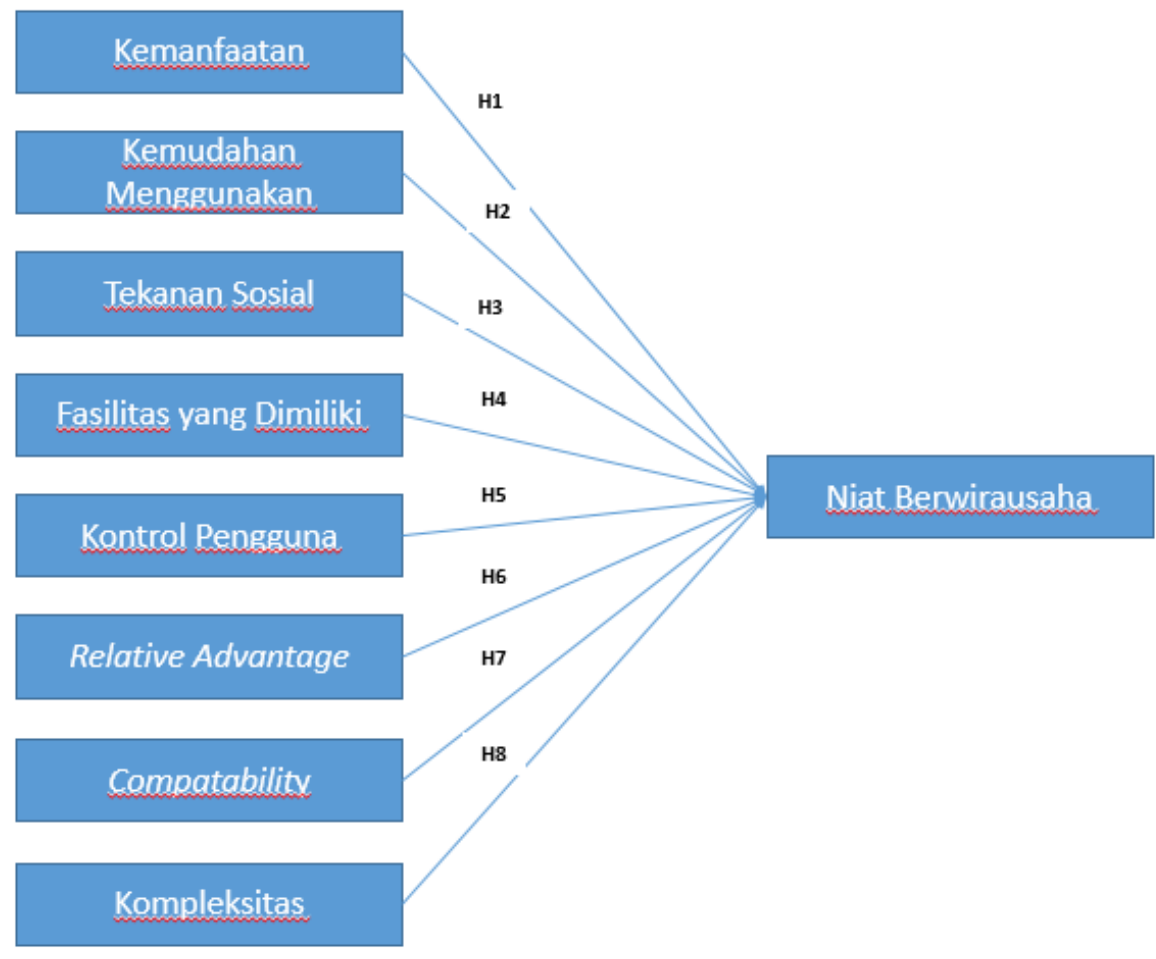

Sumber: Penelitian, 2020

Gambar 2 Keterkaitan Adopsi Media sosial dengan Niat Berwirausaha 


\section{Metode Penelitian}

Penelitian ini menggunakan metode deskriptif kuantitatif, data diambil dengan menyebarkan kuesioner kepada mahasiswa rekayasa POLBAN. Hasil kuesioner dianalisis menggunakan program SPSS. Hal ini bertujuan untuk mendapatkan hasil deskriptif masing-masing variabel dan pengaruh dari variabel independen terhadap variabel dependen yang diangkat dalam penelitian.

\section{Populasi dan Sampel}

Populasi yang akan diteliti dalam penelitian ini adalah mahasiswa tingkat akhir (D3= Tingkat 3 dan D4= Tingkat 3 \& 4) dari Jurusan Rekayasa POLBAN berjumlah 1.435 orang mahasiswa. Dengan demikian, jumlah sampel yang diambil adalah sebanyak:

$$
\begin{array}{ll}
n=\frac{N}{1+N(e)^{2}} & \begin{array}{l}
\text { Keterangan: } \\
\text { n: ukuran sampel; } \\
\text { populasi } \\
\text { e: tingkat kesalahan yang diambil dalam } \\
\text { sampling ini adalah sebesar } 0,05 \%
\end{array} \\
\mathrm{n}=\frac{1.435}{1+1.435(0,05)^{2}} & \\
\mathrm{n}=312,81 &
\end{array}
$$

Berdasarkan perhitungan dengan rumus Slovin di atas, jumlah sampel diambil adalah dibulatkan menjadi 313 orang mahasiswa. Mahasiswa yang menjadi sampel harus memenuhi kriteria sebagai berikut: a) Telah lulus MK Kewirausahaan yang diselenggarakan oleh POLBAN, dan b) Mahasiswa memiliki gadget berupa Handphone, Tablet dan/atau Laptop yang dapat mengakses media sosial.

\section{Teknik Pengambilan Sampel}

Pengambilan sampel menggunakan teknik sampling kuota, yaitu mengambil sampel pada populasi yang sesuai dengan kriteria dalam sub bab 3.1.

\section{Teknik Pengumpulan Data}

Dalam penelitian ini, teknik pengumpulan data menggunakan:

1. Penyebaran kuesioner pada mahasiswa yang memenuhi kriteria sebagaimana dijelaskan sebelumnya.

2. Wawancara terstruktur dilakukan kepada kepala prodi rekayasa di lingkungan POLBAN, data yang diperoleh guna melengkapai data yang dikumpulkan melalui penyebaran kuesioner.

3. Observasi dilakukan pada beberapa kelas yang ada pada jurusan rekayasa POLBAN.

4. Untuk melengkapi berbagai teori dan data sekunder, dilakukan studi literatur, yang bersumber dari buku, jurnal, laporan penelitian, dan data yang dipublikasi oleh BPS.

\section{Uji Validitas dan Reliabilitas}

Sebelum digunakan, alat ukur penelitian akan diuji validitasnya dengan cara mengkorelasikan skor jawaban responden dengan total jawaban responden. Sugiyono (2013: 173) menyatakan "apabila korelasi $>=0,3$ maka instrument tersebut memiliki validitas yang baik", demikian juga sebaliknya. Data-data yang diperoleh dari lapangan, sebelum digunakan akan diuji memiliki reliabilitas nilai >0,7 (Hair, et al., 2006). Untuk mempercepat pengujian validitas dan reliabilitias, dipakai SPSS 23.

\section{Analisis Data}

Untuk menjawab perumusan masalah yang telah ditetapkan, maka analisis data dilakukan dengan metode sebagai berikut:

1. Analisis regresi berganda. Digunakan untuk menganalisis masalah terkait pengaruh adopsi teknologi media sosial terhadap niat berwirausaha mahasiswa.

2. Analisis rank. Digunakan untuk mengetahui jenis media sosial yang banyak digunakan oleh mahasiswa dalam menjalankan bisnis. 


\section{Hasil dan Pembahasan}

\section{Reliabilitas dan Validitas}

Berdasarkan uji reliabilitas pada respon yang diberikan oleh responden dalam kuesioner penelitian didapat hasil sebagai berikut:

Tabel 1 Hasil Uji Reliabilitas Kuesioner Adopsi Teknologi

Reliability Statistics

\begin{tabular}{|r|r|}
\hline $\begin{array}{c}\text { Cronbach's } \\
\text { Alpha }\end{array}$ & N of ltems \\
\hline .825 & 16 \\
\hline
\end{tabular}

Sumber: Hasil Penelitian, 2020

Berdasarkan hasil pengujian yang dilakukan, kuesioner yang digunakan untuk mengukur Adopsi Teknologi Media Sosial memiliki nilai Cronbach's Alpha sebensar 0,825 > 0,7. Dengan demikian, kuesioner tersebut realiabel untuk digunakan dalam penelitian.

Tabel 2 Hasil Uji Reliabilitas Kuesioner Niat Berwirausaha

Reliability Statistics

\begin{tabular}{|c|r|}
\hline $\begin{array}{c}\text { Cronbach's } \\
\text { Alpha }\end{array}$ & N of ltems \\
\hline .778 & $\mathrm{~g}$ \\
\hline
\end{tabular}

Sumber: Hasil Penelitian, 2020

Dari hasil pengujian yang dilakukan pada kuesioner yang digunakan untuk mengukur Niat Berwirausaha, diperoleh hasil Cronbach's Alpha sebesar 0,778 >0,7. Dengan demikian, peneliti simpulkan bahwa kuesioner tersebut memiliki reliabilitas yang memadai untuk digunakan dalam penelitian. Pengujian validitas pada kuesioner yang digunakan dapat dilihat dalam tabel berikut:

Tabel 3 Hasil Uji Validitas Kuesioner

\begin{tabular}{|c|c|c|}
\hline Jenis Pengujian & Hasil & Keterangan \\
\hline $\begin{array}{l}\text { KMO and Barletts Test } \\
\text { kuesioner Adopsi Teknologi }\end{array}$ & 0,680 dengan sig. $0,000<0,05$ & - \\
\hline $\begin{array}{ll}\text { Communalities } & \text { kuesioner } \\
\text { Adopsi Teknologi } & \end{array}$ & $\begin{array}{l}\text { Semua item pertanyaan } \\
\text { memiliki nilai ekstraksi } 0,576 \\
\text { sd } 0,899 \text {. Kecuali item Q3 } \\
\text { memiliki nilai ektraksi } 0,497 \text {. }\end{array}$ & 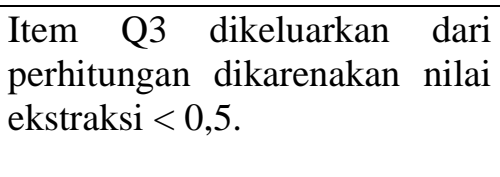 \\
\hline $\begin{array}{l}\text { KMO and Barletts Test } \\
\text { kuesioner Niat Berwirausaha }\end{array}$ & 0,662 dengan sig. $0,000<0,05$ & - \\
\hline $\begin{array}{l}\text { Communalities kuesioner Niat } \\
\text { Berwirausaha }\end{array}$ & $\begin{array}{l}\text { Terdapat beberapa item yang } \\
\text { memiliki nilai ektraksi < } 0,5 \\
\text { dengan rincian sebagai berikut: } \\
\text { Q20 }=0,485 \\
\text { Q23 }=0,472 \\
\text { Q25 }=0,434\end{array}$ & 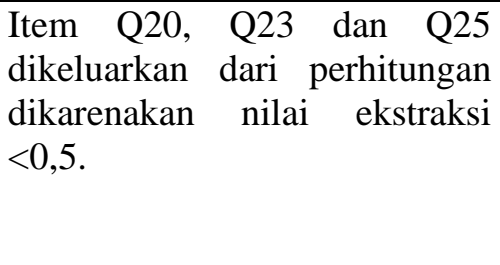 \\
\hline
\end{tabular}

Sumber: Hasil Penelitian, 2020

Berdasarkan hasil yang dilampirkan pada data di atas, dapat disimpulkan bahwa kuesioner Adopsi Teknologi Media Sosial dan Niat Berwirausaha valid untuk digunakan dalam penelitian dikarenakan 
memiliki nilai $\mathrm{KMO}>0,5$. Item dengan nilai ektraksi $<0,5$ dikeluarkan dari perhitungan karena tidak memenuhi syarat $>0,5$.

\section{Analisis Data Penelitian}

Untuk menganalisis pengaruh variabel independen terhadap variabel dependen penelitian, penelitian ini menggunakan metode analisis regresi majemuk dengan menggunakan program SPSS. Uji korelasi dilakukan untuk melihat hubungan antar variabel yang diujikan dalam penelitian ini. Adapun hasil pengujian dapat dilihat dalam tabel sebagai berikut:

Tabel 4 Tabel Correlations

\begin{tabular}{|c|c|c|c|c|c|c|c|c|c|c|}
\hline \multicolumn{11}{|c|}{ Correlations } \\
\hline & & usefulness & ease_use & social_factor & $\begin{array}{c}\text { facilitating } \\
\text { con }\end{array}$ & Control & realtive_adv & compatability & complexity & $\begin{array}{l}\text { intention_ } \\
\text { entre }\end{array}$ \\
\hline \multirow[t]{3}{*}{ usefulness } & Pearson Correlation & 1 & $.259^{\prime \prime}$ & $.356^{\prime \prime}$ & $.406^{\prime \prime}$ & $.349^{\prime \prime}$ & $.718^{\prime \prime}$ & $.583^{\prime \prime}$ & $-.353^{\prime \prime}$ & $.317^{\prime \prime}$ \\
\hline & Sig. (2-tailed) & & .000 & .000 & .000 & .000 & .000 & .000 & .000 & .000 \\
\hline & $N$ & 327 & 327 & 327 & 327 & 327 & 327 & 327 & 327 & 327 \\
\hline \multirow[t]{3}{*}{ ease_use } & Pearson Correlation & $.259^{\prime \prime}$ & 1 & $.386^{\prime \prime}$ & $477^{\prime \prime}$ & $.178^{\prime \prime}$ & $.267^{\prime \prime}$ & $.350^{\prime \prime}$ & $-.259^{\prime \prime}$ & $.195^{\prime \prime}$ \\
\hline & Sig. (2-tailed) & .000 & & .000 & .000 & .001 & .000 & .000 & .000 & .000 \\
\hline & $N$ & 327 & 327 & 327 & 327 & 327 & 327 & 327 & 327 & 327 \\
\hline \multirow[t]{3}{*}{ social_factor } & Pearson Correlation & $.356^{\prime \prime}$ & $.386^{\prime \prime}$ & 1 & $471^{\prime \prime}$ & $.159^{\prime \prime}$ & $.340^{\prime \prime}$ & $.397^{\prime \prime}$ & $-.176^{\prime \prime}$ & $.248 "$ \\
\hline & Sig. (2-tailed) & .000 & .000 & & .000 & .004 & .000 & .000 & .001 & .000 \\
\hline & $N$ & 327 & 327 & 327 & 327 & 327 & 327 & 327 & 327 & 327 \\
\hline \multirow[t]{3}{*}{ facilitating_con } & Pearson Correlation & $.406 "$ & $.477^{\prime \prime}$ & $.471^{\prime \prime}$ & 1 & $.268^{\prime \prime}$ & $.360^{\prime \prime}$ & $.416^{\prime \prime}$ & $-.216^{\prime \prime}$ & $.215^{\prime \prime}$ \\
\hline & Sig. (2-tailed) & .000 & .000 & .000 & & .000 & .000 & .000 & .000 & .000 \\
\hline & $N$ & 327 & 327 & 327 & 327 & 327 & 327 & 327 & 327 & 327 \\
\hline \multirow[t]{3}{*}{ Control } & Pearson Correlation & $.349^{\prime \prime}$ & $.178^{\prime \prime}$ & $.159^{\prime \prime}$ & $.268^{\prime \prime}$ & 1 & $.408^{\prime \prime}$ & $.365^{\prime \prime}$ & $-.221^{\prime \prime}$ & $.394^{\prime \prime}$ \\
\hline & Sig. (2-tailed) & .000 & .001 & .004 & .000 & & .000 & .000 & .000 & .000 \\
\hline & $N$ & 327 & 327 & 327 & 327 & 327 & 327 & 327 & 327 & 327 \\
\hline \multirow[t]{3}{*}{ realtive_adv } & Pearson Correlation & $.718^{\prime \prime}$ & $.267^{\prime \prime}$ & $.340^{\prime \prime}$ & $.360^{\prime \prime}$ & $408^{\prime \prime}$ & 1 & $.681^{\prime \prime}$ & $-.297^{\prime \prime}$ & $423^{\prime \prime}$ \\
\hline & Sig. (2-tailed) & .000 & .000 & .000 & .000 & .000 & & .000 & .000 & .000 \\
\hline & $N$ & 327 & 327 & 327 & 327 & 327 & 327 & 327 & 327 & 327 \\
\hline \multirow[t]{3}{*}{ compatability } & Pearson Correlation & $.583^{\prime \prime}$ & $.350^{\prime \prime}$ & $.397^{\prime \prime}$ & $.416^{\prime \prime}$ & $.365^{\prime \prime}$ & $.681^{\prime \prime}$ & 1 & $-262^{\prime \prime}$ & $.342^{\prime \prime}$ \\
\hline & Sig. (2-tailed) & .000 & .000 & .000 & .000 & .000 & .000 & & .000 & .000 \\
\hline & N & 327 & 327 & 327 & 327 & 327 & 327 & 327 & 327 & 327 \\
\hline \multirow[t]{3}{*}{ complexity } & Pearson Correlation & $-.353^{\prime \prime}$ & $-.259^{\prime \prime}$ & $-.176^{\prime \prime}$ & $-.216^{\prime \prime}$ & $-.221 "$ & $-.297^{\prime \prime}$ & $-.262^{\prime \prime}$ & 1 & $-.124^{\prime}$ \\
\hline & Sig. (2-tailed) & .000 & .000 & .001 & .000 & .000 & .000 & .000 & & .025 \\
\hline & $N$ & 327 & 327 & 327 & 327 & 327 & 327 & 327 & 327 & 327 \\
\hline \multirow[t]{3}{*}{ intention_entre } & Pearson Correlation & $.317^{\prime \prime}$ & $.195^{\prime \prime}$ & $.248^{\prime \prime}$ & $.215^{\prime \prime}$ & $.394^{\prime \prime}$ & $.423^{\prime \prime}$ & $.342^{\prime \prime}$ & $-.124^{\circ}$ & 1 \\
\hline & Sig. (2-tailed) & .000 & .000 & .000 & .000 & .000 & .000 & .000 & .025 & \\
\hline & $N$ & 327 & 327 & 327 & 327 & 327 & 327 & 327 & 327 & 327 \\
\hline
\end{tabular}

Sumber: Hasil Penelitian, 2020

Kesimpulan yang diambil dalam tabel di atas adalah sebagai berikut:

1. Variabel usefulness (kemanfaatan), ease of use (kemudahan menggunakan), sosial factor (tekanan sosial), facilitating condition (fasilitas), perceived control (kontrol pengguna), relative advantage, compatability dan complexity memiliki korelasi yang signifikan terhadap variabel niat berwirausaha. Ditandai dengan nilai signifikansi< 0,05 .

2. Variabel independen saling berkorelasi dengan signifikansi $<0,05$.

Tabel 5 Tabel Model Summary

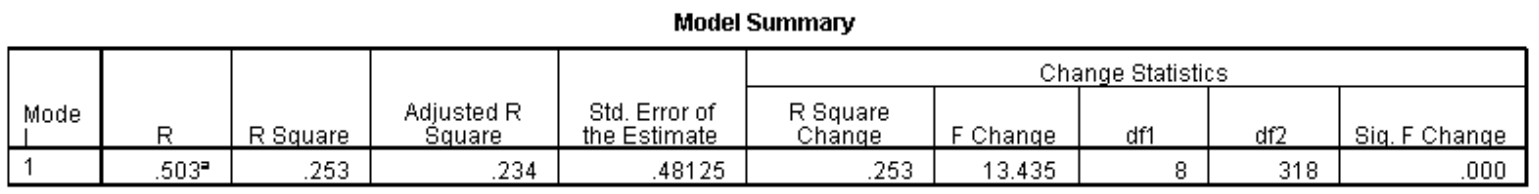

a. Predictors: (Constant), complexity, social_factor, Control, ease_use, usefulness, facilitating_con, compatability, realtive_adv

Sumber: Hasil Penelitian, 2020

Berdasarkan tabel di atas, disimpulkan bahwa variabel independen yang terdiri dari usefulness (kemanfaatan), ease of use (kemudahan menggunakan), sosial factor (tekanan sosial), facilitating condition (fasilitas), perceived control (kontrol pengguna), relative advantage, compatability dan 
complexity memiliki pengaruh simultan terhadap variabel dependen (niat berwirausaha) sebesar 25,3\%. $74,7 \%$ sisanya dipengaruhi oleh variabel lain yang tidak diteliti dalam penelitian ini.

Tabel 6 Tabel ANOVA

ANONA ${ }^{b}$

\begin{tabular}{|ll|r|r|r|r|r|}
\hline \multicolumn{1}{|c|}{} & \multicolumn{1}{c|}{$\begin{array}{c}\text { Sum of } \\
\text { Squdel }\end{array}$} & \multicolumn{1}{c|}{ df } & Mean Square & \multicolumn{1}{c|}{$\mathrm{F}$} & Sig. \\
\hline 1 & Regression & 24.892 & 8 & 3.111 & 13.435 & $.000^{=}$ \\
& Residual & 73.649 & 318 & .232 & & \\
& Total & 98.541 & 326 & & & \\
\hline
\end{tabular}

a. Predictors: (Constant), complexity, social_factor, Control, ease_use, usefulness, facilitating_con, compatability, realtive_adv

b. Dependent Variable: intention_entre

Sumber: Hasil Penelitian, 2020

Pengujian simultan yang dilakukan pada variabel independen didapat angka $F_{\text {hitung }} 13.435$ dengan sig. $0,000<0,05$. Dengan demikian, dapat dismpulkan bahwa semua variabel independen dalam penelitian ini memberikan pengaruh signifikan pada variabel niat berwirausaha.

Tabel 7 Tabel Coefficients

Coefficients ${ }^{3}$

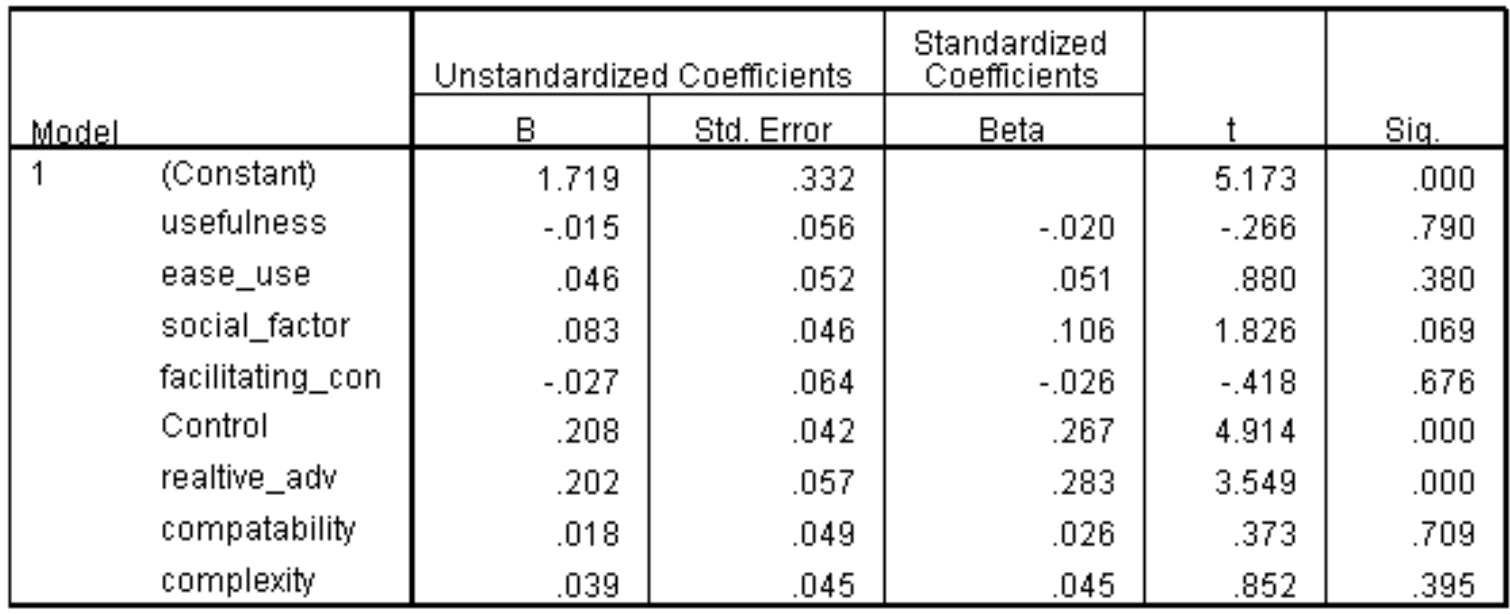

a. Dependent Variable: intention_entre

Sumber: Hasil Penelitian, 2020

Tabel Coefficients menunjukkan data terkait pengaruh parsial masing-masing variabel independen terhadap variabel dependen yang ada dalam penelitian ini. Penjelasan terkait tabel di atas adalah sebagai berikut:

1. Variabel perceived control memiliki pengaruh positif dan signifikan terhadap variabel niat berwirausaha ditandai dengan nilai thitung 4.914 dengan sig. $0,000<0,05$. Dengan demikian, hipotesis 5 yang menyatakan kontrol pengguna (perceived control) berpengaruh pada niat berwirausaha mahasiswa rekayasa POLBAN terdukung.

2. Variabel relative advantage juga memberikan pengaruh positif dan signifikan terhadap niat berwirausaha mahasiswa dengan nilai $t_{\text {hitung }} 3.549$ dengan sig. $0,000<0,05$. Dengan demikian, 
hipotesis 6 yang menyatakan bahwa relative advantage berpengaruh positif pada niat berwirausaha mahasiswa rekayasa POLBAN terdukung.

3. Variabel usefulness, ease of use, sosial factor, facilitating condition, compatability dan complexity tidak memberikan pengaruh signifikan terhadap niat berwirausaha mahasiswa ditandai dengan nilai sig. $>0,05$. Dengan demikian, semua hipotesis yang berkaitan dengan variabel tersebut tidak terdukung.

4. Nilai koefisien variabel perceived control 0,208 dan nilai koefisien variabel niat berwirausaha dengan asumsi variabel lain tetap adalah 1.719. Dengan demikian, disimpulkan bahwa setiap ada kenaikan satu satuan pada variabel perceived control maka akan memberikan kenaikan pada niat berwirausaha sebesar 0,208.

5. Nilai koefisien variabel relative advantage 0,202 dan nilai koefisien variabel niat berwirausaha dengan asumsi variabel lain tetap adalah 1.719. Dengan demikian, disimpulkan bahwa setiap ada kenaikan satu satuan pada variabel relative advantage maka akan memberikan kenaikan pada niat berwirausaha sebesar 0,202.

\section{Media Sosial yang Digunakan}

Berdasarkan data yang diperoleh dalam penelitian, aplikasi media sosial yang banyak digunakan oleh mahasiswa jurusan rekayasa POLBAN adalah sebagai berikut:

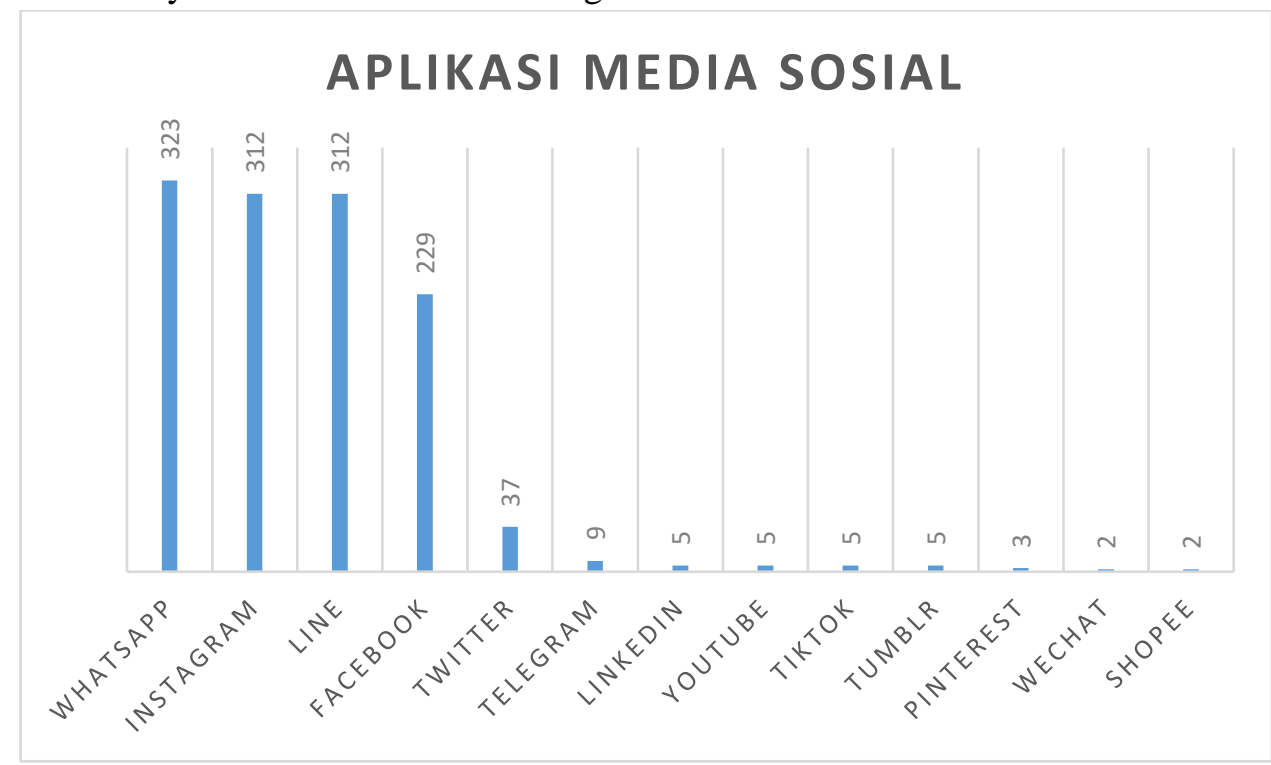

Sumber: Hasil Penelitian, 2020

Gambar 3 Sosial Media yang Banyak Digunakan

Berdasarkan diagram di atas, lima besar aplikasi media sosial yang banyak dipergunakan oleh mahasiswa di jurusan rekayasa POLBAN adalah Whatsapp dengan 323 pengguna, Instagram dan Line dengan 312 pengguna, Facebook dengan 229 pengguna dan Twitter dengan 37 mahasiswa pengguna. Terdapat aplikasi lain yang digunakan namun tidak secara masif oleh mahasiswa yaitu Telegram, Linkedin, Youtube dan lain-lain. Banyaknya suatu aplikasi digunakan oleh penggunanya dipengaruhi oleh oleh userfriendly aplikasi yang dirancang oleh penyedia media sosial (Wang \& Lin, 2016), memiliki cangkupan yang luas dan murah (Jagongo \& Kinyua, 2013).

\section{Pembahasan}

Penelitian ini menunjukkan bahwa variabel usefulness (kemanfaatan), ease of use (kemudahan menggunakan), sosial factor (tekanan sosial), facilitating condition (fasilitas), perceived control (kontrol pengguna), relative advantage, compatability dan complexity dalam pemanfaatan teknologi media sosial secara simultan berpengaruh pada niat berwirausaha mahasiswa jurusan rekayasa 
POLBAN. Manfaat yang diberikan, kemudahan dalam menggunakan, penggunaan oleh rekan dan keluarga, kemampuan dalam mengontrol penggunaan, keunggulan dan kesesuaian dengan kegiatan yang dilakukan oleh mahasiswa menjadi faktor yang mempengaruhi niat berwirausaha mahasiswa dengan penggunaan teknologi media sosial sebagai suatu sarana dalam berwirausaha.

Hasil uji regresi majemuk yang dilakukan menunjukkan bahwa:

a. Perceived control yang dimiliki mahasiswa atas penggunaan media sosial memberikan pengaruh yang signifikan pada niat berwirausaha mahasiswa. Kemampuan mahasiswa dalam mengendalikan penggunaan dan tujuan dari pemanfaatan media sosial dapat memberikan keuntungan yang kuat bagi mahasiswa melalui konsistensi tujuan yang hendak dicapai dari penggunaan tersebut. Hal ini sejalan dengan penelitian sebelumnya yang menemukan bahwa kemampuan dalam mengontrol penggunaan berpengaruh positif bagi minat berwirausaha (Chaniago \& Sayuti, 2019; Luciana \& T, 2018; Potishuk \& Kratzer, 2017; Yzer, 2012). Kemampuan mengendalikan diri dalam menggunakan media sosial untuk mengidentifikasi pasar, menentuan segmen yang hendak disasar tanpa terbuai dengan penggunaan media sosial yang bertujuan untuk membunuh waktu semata. Mahasiswa memahami betul bahwa dia harus bisa secara konsisten memanfaatkan sisi positif dari penggunaan media sosial yang digunakannya (Chaniago \& Sayuti, 2019; Yzer, 2012).

b. Relative advantage (keunggulan) yang diterima mahasiswa dari penggunaan media sosial juga mempengaruhi meningkat tidaknya niat berwirausaha mahasiswa jurusan rekayasa POLBAN. Keunggulan ini memberikan persepsi positif kepada mahasiswa bahwa dengan adanya penggunaan media sosial yang masif memberikan manfaat lebih padanya dalam menjalankan kegiatan sehari-harinya (Surachim et al., 2018). Kegiatan yang dilakukan menjadi lebih efektif dan berjalan dengan efisien dengan bantuan media sosial yang digunakan (Moghavvemi et al., 2010). Dalam konteks wirausaha, keunggulan tersebut ditandai komunikasi kepada calon konsumen menjadi semakin tanpa jarak, presentasi yang digunakan dapat langsung dilakukan dengan bantuan media sosial yang digunakan tanpa harus mengeluarkan biaya transportasi yang semakin membengkak. Hingga kegiatan wirausaha dapat berjalan dengan lebih efektif dan dengan biaya yang sebagai mana mestinya tanpa adanya pembengkakan pada pos-pos yang seharusnya dapat dilakukan penghematan.

Dalam konteks pendidikan tinggi, selain dua hal di atas beberapa upaya yang dapat dilakukan untuk meningkatkan niat berwirausaha adalah sebagai berikut (Ambad \& Damit, 2016; Chaniago \& Sayuti, 2019; Lesáková, 2012; Obaji et al., 2015; Potishuk \& Kratzer, 2017):

a. Dukungan pendidikan berupa keselarasan kurikulum yang diajarkan dengan tujuan kewirausaha. Mahasiswa diajarkan pengetahuan dan keterampilan tentang berwirausaha.

b. Dukungan struktural dari pemerintah dan swasta dalam menciptakan iklim kewirausahaan.

c. Dukungan relasional berupa dukungan emosional dan panutan dari orang-orang terdekat untuk berwirausaha.

Dukungan inkubator bisnis berupa pendampingan, pelatihan hingga pendanaan untuk menjalankan proses bisnis ketika kegiatan usaha baru didirikan.

\section{Kesimpulan}

Berdasarkan pembahasan yang dijabarkan dalam penelitian ini, kesimpulan yang dirumuskan adalah pertama, variabel usefulness (kemanfaatan), ease of use (kemudahan menggunakan), sosial factor (tekanan sosial), facilitating condition (fasilitas), perceived control (kontrol pengguna), relative advantage, compatability dan complexity secara simultan memberikan pengaruh signifikan pada variabel niat berwirausaha mahasiswa. Kedua, secara parsial, hanya variabel perceived control (kemampuan mengontrol) dan relative advantage yang memberikan pengaruh pada variabel niat berwirausaha. Ketiga, aplikasi media sosial yang banyak digunakan oleh mahasiswa rekayasa POLBAN adalah Whatsapp, Instagram, Line dan Facebook.

\section{Daftar Pustaka}

Alarcon-del-Amo, M.-C., Josep, R., \& Criado, A. R. (2015). The effect of social media adoption on exporting firms' performance. Advances in International Marketing, 25(January), 161-186. https://doi.org/10.1108/S1474-797920140000025007 
Ambad, S. N. A., \& Damit, D. H. D. A. (2016). Determinants of Entrepreneurial Intention Among Undergraduate Students in Malaysia. Procedia Economics and Finance, 37(16), 108-114. https://doi.org/10.1016/s2212-5671(16)30100-9

Ambadar, J., Abidin, M., \& Isa, Y. (2007). Membentuk Karakter Pengusaha. Mizan Digital Publishing. https://books.google.co.id/books?id=xqd9AwAAQBAJ\&printsec=frontcover\&hl=id\#v=onepage $\& \mathrm{q} \& \mathrm{f}=$ false

Asosiasi Penyelenggara Jasa Internet Indonesia. (2016). Penetrasi dan Perilaku Pengguna Internet Indonesia 2016 (Issue June).

Badran, I. (2007). Enhancing creativity and innovation in engineering education. European Journal of Engineering Education, 32(5), 573-585. https://doi.org/10.1080/03043790701433061

BPS (2017). Pengangguran Terbuka Menurut Pendidikan Tertinggi yang Ditamatkan 1986-2017. Jakarta, Indonesia: Badan Pusat Statistik.

Chaniago, H., \& Sayuti, A. M. (2019). Peran Adopsi Teknologi Social Media Terhadap Niat Berwirausaha Mahasiswa Studi pada Mahasiswa Vokasi Non Rekayasa Polban. Jurnal Riset Bisnis Dan Investasi, 5(3).

Constantinides, E., Lorenzo, C., \& Gomez-Borja, M. A. (2009). Social Media: A New Frontier for Retailers? European Retail Research (Volume 22), August 2016, 1-227. https://doi.org/10.1007/978-3-8349-8099-1

Daryanto. (2012). Pendidikan Kewirausahaan, Yogyakarta: Gavamedia

Davis, F. D. (1989). Perceived usefulness, perceived ease of use, and user acceptance of information technology. MIS Quarterly: Management Information Systems, 13(3), 319-339. https://doi.org/10.2307/249008

Fourqoniah, F. (2015). Pengaruh Jejaring Sosial Online Terhadap Intensi Berwirausaha Mahasiswa Program Sarjana di Indonesia | FOURQONIAH | DISERTASI dan TESIS Program Pascasarjana UM. Program Studi Pendidikan Ekonomi, Pascasarjana, Universitas Negeri Malang. http://karyailmiah.um.ac.id/index.php/disertasi/article/view/38367

Hartati, E. R. (2017). UMKM Sehat, Negara Kuat. Berita Satu. https://www.beritasatu.com/ekonomi/436811/umkm-sehat-negara-kuat

Jagongo, A., \& Kinyua, C. (2013). The Social Media and Entrepreneurship Growth ( A New Business Communication Paradigm among SMEs in Nairobi ). International Journal of Humanities and Social Science, 3(10), 213-227.

Kim, J. H., Bae, Z. T., \& Kang, S. H. (2008). The role of online brand community in new product development: Case studies in digital product manufacturers in Korea. International Journal of Innovation Management, 12(3), 357-376. https://doi.org/10.1142/S1363919608002011

Lesáková, L. (2012). The role of business incubators in supporting the SME start-up. Acta Polytechnica Hungarica, 9(3), 85-95.

Liñán, F., \& Santos, F. J. (2007). Does social capital affect entrepreneurial intentions? International Advances in Economic Research, 13(4), 443-453. https://doi.org/10.1007/s11294-007-9109-8

Luciana, M., \& T, G. A. S. (2018). ANALISIS FAKTOR-FAKTOR YANG BERPENGARUH TERHADAP NIAT BERWIRAUSAHA WANITA DENGAN PENDEKATAN THEORY OF PLANNED BEHAVIOR ( Studi Kasus Pada Wirausaha Wanita Pemilik UMKM Di Bandung ) ANALYSIS OF FACTORS AFFECTING WOMEN ENTREPRENEURIAL INTENT USING THEORY OF. E-Proceeding of Management, 5(2), 1593-1600.

Moghavvemi, S., Akma, N., Salleh, M., \& Standing, C. (2010). Entrepreneurs Adoption of Information System Innovation: The Impact of Individual Perception and Exogenous Factors on Entrepreneurs Behavior. Internet Research, Unit 07, 1-5.

Obaji, N. O., Onyemerela, C., \& Olugu, M. U. (2015). Entrepreneurship and Business Incubation Programme: the Sure Couple. International Journal of Science, Technology and Management, $4(1), 1627-1633$.

Piller, F. T., \& Walcher, D. (2006). Toolkits for idea competitions: A novel method to integrate users in new product development. $R$ and $D$ Management, 36(3), 307-318. https://doi.org/10.1111/j.1467-9310.2006.00432.x

Potishuk, V., \& Kratzer, J. (2017). Factors affecting entrepreneurial intensions and entrepreneurial 
attitudes in higher education. Journal of Entrepreneurship Education, 20(1), 25-44.

Pribadi, A., Ghozali, K., Hidayanto, B. C., Hafidz, I., Muqtadiroh, F. A., Hafidz, M. Al, Sintiya, E. S., Puspitaningrum, A. C., \& Sari, R. (2018). Pelatihan Teknik Social Media Marketing sebagai Sarana Pemasaran Produk pada Konveksi Kerudung ‘Al- Kattar' Di Kelurahan Merjosari, Malang. Sewagati, 2(1). https://doi.org/10.12962/j26139960.v2i1.3196

Raymond, L., \& Bergeron, F. (2008). Enabling the business strategy of SMEs through e-business capabilities: a Strategic Alighment Perspective. Industrial Management \& Data Systems, 108(5), 577-595. https://doi.org/10.1108/02635570810876723

Rizkinaswara, L. (2019). Millenials Top Brand Award 2019, Menggali Potensi Besar Ekonomi Digital Indonesia - Ditjen Aptika. Kementerian Komunikasi Dan Informatika RI. https://aptika.kominfo.go.id/2019/01/millenials-top-brand-award-2019-menggali-potensi-besarekonomi-digital-indonesia/

Roblyer, M. D., McDaniel, M., Webb, M., Herman, J., \& Witty, J. V. (2010). Findings on Facebook in higher education: A comparison of college faculty and student uses and perceptions of social networking sites. Internet and Higher Education, 13(3), 134-140. https://doi.org/10.1016/j.iheduc.2010.03.002

Rodrigues Pinho, J. C. M., \& Soares, A. M. (2011). Examining the technology acceptance model in the adoption of social networks. Journal of Research in Interactive Marketing, 5(October 2015), 116129. https://doi.org/10.1108/17505931111187767

Rogers, E. M. (1983). Diffusion of innovations 3rd Edition. In An Integrated Approach to Communication Theory and Research, Third Edition. https://doi.org/10.4324/9780203710753-35

Sinkovics, N., Sinkovics, R. R., \& Jean, R. J. B. (2013). The internet as an alternative path to internationalization? In International Marketing Review (Vol. 30, Issue 2). https://doi.org/10.1108/02651331311314556

Sugiyono (2013). Metode Penelitian Kuantitatif, Kualitatif dan R\&D. Bandung: Alfabeta.

Surachim, A., Hurriyati, R., Lisnawati, L., Sulastri, S., \& Mulyadi, H. (2018). Using social media to promote student entrepreneurship. Pertanika Journal of Social Sciences and Humanities, 26(T), 173-183.

Taprial, V., \& Kanwar, P. (2012). Understanding Social Media. bookboon.com.

Venkatesh, V., Morris, M. G., Davis, G. B., \& Davis, F. D. (2003). User Acceptance of Information Technology: Toward a Unified View. MIS Quarterly, 27(3), 425-478. https://doi.org/10.1201/9780849375477.ch230

Wagner, B., Fillis, I., \& Johansson, U. (2003). E-business and e-supply strategy in small and medium sized businesses ( SME ). Suplly Chain Management, 8(3/4), 343.

Wang, Y.-M., \& Lin, Y.-S. (2016). Determinants of Internet Entrepreneurship Intentions among Business School Students. International Journal of Information and Education Technology, 6(10), 754-758. https://doi.org/10.7763/ijiet.2016.v6.787

Wijaya, T. (2008). Kajian Model Empiris Perilaku Berwirausaha UKM DIY dan Jawa Tengah. Jurnal Manajemen Dan Kewirausahaan (Journal of Management and Entrepreneurship), 10(2), 93-104104. https://doi.org/10.9744/jmk.10.2.pp.93-104

Winardi, J. (2008). Entrepreneur dan Entrepreneurship, Jakarta: Kencana

Yzer, M. (2012). Perceived behavioral control in reasoned action theory: A dual-aspect interpretation. Annals of the American Academy of Political and Social Science, 640(1), 101-117. https://doi.org/10.1177/0002716211423500

\section{*Email korespondensi:}

harmon@polban.ac.id 